\title{
KETERAMPILAN SOSIAL \\ ANAK KELUARGA PENERIMA MANFAAT PROGRAM KELUARGA HARAPAN \\ DI DESA CIENTEUNG KECAMATAN DARMARAJA KABUPATEN SUMEDANG JAWA BARAT
}

\author{
Krisna Dewi Setianingsih \\ Politeknik Kesejahteraan Sosial , krisna_dewi@poltekesos.ac.id
}

\begin{abstract}
Abstrak
Keterampilan sosial anak Keluarga Penerima Manfaat merupakan suatu keterampilan yang sangat penting bagi anak untuk mencapai keberhasilan di bidang pendidikan sesuai dengan tujuan dari Program Keluarga Harapan. Penelitian ini bertujuan untuk untuk menggambarkan keterampilan sosial anak Keluarga Penerima Manfaat Program Keluarga Harapan berdasarkan jenis kelamin serta tingkat pendidikannya. Penelitian ini menggunakan disain pendekatan kuantitatif deskriptif dan pengumpulan data dilakukan melalui kuesioner keterampilan sosial terhadap 119 anak yang menjadi responden penelitian. Responden adalah sampel yang terpilih dengan menggunakan Tabel Isaac dan Michael. Hasil penelitian menunjukkan bahwa sebagian besar keterampilan sosial anak dari Keluarga Penerima Manfaat PKH baik laki-laki maupun perempuan, yang berada pada tingkat pendidikan SLTP maupun SLTA berada pada kategori sedang yaitu berkisar antara 57\% - 62\%. Hasil penelitian juga menunjukkan bahwa anak perempuan di tingkat pendidikan SLTP ada 67,64\% yang keterampilan sosialnya mencapai kategori tinggi. Namun demikian hasil peneltian juga menunjukkan bahwa masih terdapat anak-anak yang memiliki keterampilan sosial pada kategori rendah yaitu sekitar 20\%. Rekomendasi: 1) perlu pengembangan modul pelatihan keterampilan sosial untuk Pertemuan Peningkatan Kemampuan Keluarga yang diarahkan pada keterampilan sosial anak Keluarga Penerima Manfaat PKH; 2) peningkatan kapasitas pendamping PKH untuk intervensi keterampilan sosial anak; 3) peningkatan kapasitas Keluarga Penerima Manfaat PKH dalam meningkatkan keterampilan sosial anak.
\end{abstract}

Kata Kunci: Keterampilan Sosial, Anak, Keluarga Penerima Manfaat PKH

\section{Abstract}

The social skills of beneficiary families' children are very important skills for children to achieve success in education in accordance with the objectives of the Harapan Family Program. This study aims to describe the social skills of beneficiary families of the Harapan Family Program based on their gender and educational level. This study used a descriptive quantitative approach design and data collection was carried out through a social skills questionnaire to 119 children who were research respondents. Respondents are a sample selected using Isaac and Michael's Tables. The results showed that most of the social skills of children from PKH beneficiary families, both boys and girls, who were at the junior and senior high school education levels were in the medium category, which ranged from $57 \%-62 \%$. The results also showed that there were $67.64 \%$ girls in junior high school whose social skills reached the high category. However, the research results also show that there are still children who have social skills in the low 
category, which is around $20 \%$. Recommendations: 1) it is necessary to develop a social skills training module for the Family Capacity Building Meeting directed at the social skills of PKH beneficiary families; 2) capacity building of $\mathrm{PKH}$ facilitators for children's social skills interventions; 3) increasing the capacity of PKH beneficiary families in improving children's social skills.

Keywords: Social Skills, Children,PKH,Beneficiary Family

\section{PENDAHULUAN}

Keluarga Penerima Manfaat (KPM) Program Keluarga Harapan (PKH) dalam Peraraturan Menteri Sosial No. 1 Tentang PKH adalah keluarga miskin dan rentan yang terdaftar dalam Data Terpadu Program Penanganan Fakir Miskin yang memiliki komponen kesehatan dengan kriteria keluarga yang memilki ibu hamil/enyusui, anak berusia nol sampai dengan enam tahun.; komponen pendidikan dengan kriteria keluarga yang memiliki anak SD, SLTP dan SLTA, dan anak usia 6 sampai 21 tahun yang belum menyelesaikan wajib belajar 12 tahun. Sejak tahun 2016 terdapat penambahan komponen kesejahteraan sosial dengan kriteria keluarga yang memiliki lanjut usia dan diutamakan mulai dari enam puluh tahun, serta keluarga yang memiliki penyandang disabilitas dan diutamakan penyandang disabilitas berat.

Berdasarkan penjelasan tersebut bahwa keluarga miskin yang mempunyai anak usia sekolah merupakan salah satu Keluarga Penerima Manfaat PKH. Melalui bantuan $\mathrm{PKH}$, diharapkan anak-anak dari keluarga miskin dapat menyelesaikan wajib belajar 12 tahun atau pendidikan SLTA. Hal tersebut sesuai dengan tujuan dari PKH yaitu untuk mengurangi angka dan memutus rantai kemiskinan, meningkatkan kualitas sumber daya manusia, serta mengubah perilaku yang kurang mendukung peningkatan kesejahteraan dari kelompok yang paling miskin. Keluarga Penerima Manfaat PKH hanya akan menerima bantuan apabila anak-anaknya bersedia mengikuti pendidikan pada tingkat pendidikan tertentu sesuai dengan usia belajarnya, dan bantuan akan diberikan jika anak-anak dari Keluarga Penerima Manfaat PKH memiliki laporan kehadiran di sekolah yang diverifikasi oleh pihak yang mempunyai tanggung jawab di dalam Program Keluarga Harapan .

Keberhasilan anak-anak didalam menyelesaikan pendidikannya membutuhkan dukungan dari berbagai pihak, seperti keluarga, teman-teman, guru serta orang dewasa lainnya yang ada di lingkungan sosial anak. Namun demikian untuk akses terhadap dukungan tersebut anak perlu memiliki keterampilan yang dapat bermanfaat bagi anak untuk melakukan interaksi sosial, melakukan percakapan, dan keterampilan lain yang termasuk didalam keterampilan sosial. Keterampilan sosial menurut Gresham (2016) merupakan suatu sekumpulan perilaku yang dipelajari yang memberikan manfaat kepada individu untuk mengembangkan hubungan dengan orang lain dan mendapatkan respon sosial yang baik. Keterampilan sosial sangat penting untuk meraih kesuksesan pada masa kanakkanak maupun pada saat dewasa. Selanjutnya Gresham menjelaskan bahwa keterampilan sosial mencakup beberapa keterampilan, yaitu: 1) kerjasama; 2) asertif; 
tanggungjawab; 4) empati; dan 5) kendali diri .Perkembangan keterampilan sosial anak awal mulanya terjadi di lingkungan keluarga. Keluargalah yang menjadi agen utama di dalam membantu anak untuk mengembangkan keterampilan-keterampilan yang penting bagi kehidupan termasuk keterampilan sosial. Namun demikian anakanak yang tumbuh di dalam lingkungan keluarga dengan status ekonomi rendah mempunyai resiko mengalami habatan di dalam perkembangan keterampilan sosialnya. Kondisi kehidupan dari keluarga miskin sebagaimana yang digambarkan dari hasil penelitian Evans (dalam Jensen, 2009) bahwa keluarga dengan penghasilan rendah umumnya kurang dapat melacak di lingkungan mana anak-anak mereka berada, dan seringkali mereka tidak mengenal guru atau teman anak-anak mereka. Satu studi menunjukkan bahwa hanya 36 persen orang tua berpenghasilan rendah yang terlibat dalam tiga atau lebih kegiatan sekolah secara teratur. Kondisi tersebut menggambarkan bahwa orang tua berpenghasilan rendah jarang sekali berpartisipasi didalam pendidikan anak-anaknya karena kesibukan mereka didalam mencari nafkah, bahkan orang tua juga kurang memiliki kemampuan untuk mendeteksi anak-anaknya berada di lingkungan pergaulan yang seperti apa.

Anak yang hidup dalam kondisi tersebut tentunya tidak memiliki model bagi pengembangan keterampilan sosialnya, karena keterampilan sosial hanya akan berkembang jika anak memiliki kesempatan yang cukup untuk berinteraksi dengan lingkungan sosialnya, khususnya dengan keluarganya. Sebagaimana pendapat
Sokolowski et al. (dalam Jensen, 2009) bahwa anak membutuhkan model untuk pengembangan emosi yang tepat atau merespon orang lain dengan tepat, mereka membutuhkan interaksi dengan orang-orang yang penting di dalam kehidupannya. Kegagalan untuk membentuk hubungan yang positif dengan teman sebaya menimbulkan konsekuensi sosial jangka panjang. .

Keegan-Ramon \& Zuehl (2001) dalam sebuah studi tentang masalah emosional anak-anak dari ibu tunggal menemukan bahwa tekanan kemiskinan meningkatkan depresi dikalangan ibu yang berdampak pada peningkatan hukuman fisik (Jensen, 2009). Menurut penjelasan Deñny, Clark, Feeling, \& Wall (2004) bahwa anakanak sendiri juga rentan terhadap depresi (Jensen, 2009).

Dari gambaran tersebut nampak bahwa hubungan yang kuat dan aman antara anak dengan keluarganya membantu menstabilkan perilaku anak dan memberikan panduan yang diperlukan untuk membangun keterampilan sosial di masa dewasa. Keluarga menjadi area anak untuk belajar memberikan respon emosional yang sehat dan sesuai dengan situasi sehari-hari yang selanjutnya menjadi dasar bagi perkembangan keterampilan sosial anak.

Evans (dalam Jensen, 2009) menggambarkan bahwa anak-anak yang dibesarkan dalam kemiskinan cenderung menampilkan perilaku bermasalah, ketidaksabaran dan impulsif, reaksi emosional yang tidak tepat, kurang mampu memberikan empati terhadap orang lain. Anak-anak dari keluarga berpenghasilan rendah menerima lebih sedikit stimulasi kognisi, seperti orang tuanya jarang 
membacakan cerita kepada mereka. Anakanak dari keluarga berpenghasilan rendah juga cenderung tidak dilatih keterampilan belajar atau dibantu dalam menyelesaikan pekerjaan rumah. Mereka juga memiliki sedikit sarana bermain di rumahnya, sedikit memiliki akses ke komputer dan internet (kurang terampil dalam mengoperasikannya), memiliki sedikit buku, sarana rekreasi dan bahan pembelajaran lainnya, lebih banyak menghabiskan waktunya di rumah dan kurang memiliki teman untuk bermain.

Menurut Brooks-Gunn, \& Duncan, 1997; Miltèer et al. 2012 bahwa anak-anak dari keluarga berpenghasilan rendah mungkin tidak menerima pengembangan keterampilan sosial yang diperlukan di rumah, maka lingkungan sekolah menjadi arena yang penting untuk membantu anak di dalam mengembangkan keterampilan tersebut melalui interaksinya di kelas, khususnya melalui hubungan teman sebaya (Barnes, 2007). Hubungan teman sebaya dan teman bermain berfungsi sebagai faktor pelindung dan memfasilitasi pengembangan keterampilan sosial yang penting. Keterampilan sosial sangat penting bagi keberhasilan akademik, yang akan menjadi alat bagi anak-anak dari keluarga berpenghasilan rendah untuk berjuang keluar dari kondisi kemiskinan.

Menurut Milteer, Ginsburg, \& Mulligan, (2012); Stuhlman \& Piantra, (2009) bahwa terlibat dalam hubungan teman sebaya di sekolah dapat membantu siswa dari keluarga miskin meningkatkan keterampilan sosial mereka, meningkatkan keterlibatan di sekolah, dan membantu mereka memiliki pandangan positif tentang sekolah, tentang hubungan yang terbentuk dan tentang proses pembelajaran (Barnes, 2007).

Berdasarkan gambaran tentang kondisi anak- anak yang hidup di dalam kemiskinan berisiko di dalam mengembangkan keterampilan sosial yang sangat penting untuk meraih keberhasilan di dunia pendidikannya dan juga di dalam kehidupan bermasyarakat, maka sangat menarik untuk mengetahui bagaimana keterampilan sosial anak-anak dari keluarga miskin sebagai Keluarga Penerima Manfaat PKH. Anak Keluarga Penerima Manfaat PKH perlu memiliki keterampilan sosial yang bermanfaat untuk membantunya di dalam menyelesaikan wajib belajar 12 tahun sebagai persyaratan untuk mendapatkan bantuan PKH. Di Desa Cienteung Kecamatan Darmaraja Kabupaten Sumedang diketahui terdapat 335 anak usia sekolah dari Keluarga Penerima Manfaat PKH, baik yang ada di tingkat SD, SLTP maupun SLTA. Di dalam penelitian ini hanya difokuskan kepada anak-anak Keluarga Penerima Manfaat PKH yang sedang belajar di tingkat SLTP dan SLTA dengan alasan bahwa anak SLTP dan SLTA perkembangan kognitifnya sudah mencapai tingkat operasi formal, artinya anak sudah mampu untuk berfikir abstrak sehingga anak dapat memahami pertanyaan atau pernyataan yang disampaikan di dalam kuesioner penelitian.

Penelitian ini dilaksanakan di Desa Cienteung Kecamatan Darmaraja Kabupaten Sumedang, karena selain Desa Cieunteung merupakan salah satu wilayah yang warganya mendapatkan bantuan $\mathrm{PKH}$, Desa Cienteung memiliki hubungan kerjasama dengan Politeknik Kesejahteraan 
Sosial, yaitu sebagai wilayah kegiatan praktikum mahasiswa Program Studi Sarjana Terapan. Berdasarkan latar belakang yang telah dijelaskan maka permasalahan penelitian adalah : "Keterampilan sosial anak Keluarga Penerima Manfaat PKH di Desa Cienteung?" dengan sub permasalahan penelitian mencakup: 1) demografi anakanak Keluarga Penerima Manfaat PKH; 2) Keterampilan sosial anak Keluarga Penerima Manfaat PKH berdasarkan tingkat pendidikan?; 3) Keterampilan sosial anak Keluarga Penerima Manfaat PKH berdasarkan jenis kelamin

\section{METODE PENELITIAN}

\section{Desain Penelitian}

Penelitian ini menggunakan metode deskriptif dengan pendekatan kuantitatif untuk menggambarkan keterampilan sosial anak Keluarga Penerima Manfaat PKH di Desa Cienteung Kabupaten Sumedang secara akurat.

\section{Populasi dan Sampel}

Populasi dari penelitian ini adalah anak Keluarga Penerima Manfaat PKH sebanyak 172 anak yang sedang belajar di SLTP dan SLTA. Responden penelitian dipilih dengan menggunakan Tabel Isaac \& Michael (dalam Soegiyono, 2015) dan diperoleh 114 anak, untuk mengantisipasi jawaban responden yang tidak lengkap maka jumlah sampel ditingkatkan menjadi 119 anak. Selanjutnya penentuan sampel berdasarkan tingkat pendidikan digunakan Simple Random Sampling sehingga diperoleh sampel dari tingkat pendidikan SLTP sejumlah 87 anak dan dari tingkat pendidikan SLTA diperoleh 85 anak.

\section{Teknik Pengumpulan Data}

Pengumpulan data dalam penelitian ini menggunakan kuesioner Keterampilan Sosial yang terdiri dari 35 item pernyataan untuk mendapatkan data tentang keterampilan sosial anak Keluarga Penerima Manfaat PKH.

\section{Validitas dan Reliabilitas}

Sebelum instrumen penelitian digunakan maka dilakukan uji coba terlebih dahulu terhadap 29 anak dari keluarga miskin. Uji validitas menggunakan metode Pearson dan hasilnya menunjukkan bahwa nilai $r$ hitung untuk keseluruhan item diketahui paling kecil adalah 400 yaitu lebih besar daripada nilai $r$ tabel untuk $\mathrm{N}=29$ yaitu 0,367, artinya instrumen dikatakan valid. Uji reliabilitas menggunakan Cronbach's Alpha dan hasil penghitungan dengan menggunakan program SPSS nilainya 0,838 $>0.60$ sehingga instrumen dinyatakan reliabel.

\section{HASIL PENELITIAN}

Penelitian keterampilan sosial anak Keluarga Penerima Manfaat PKH dilaksanakan di Desa Cieunteung, yang menjadi salah satu wilayah penerima bantuan PKH di Kabupaten Sumedang Propinsi Jawa Barat. Berikut adalah hasil penelitian:

\section{Desa Cienteung Kecamatan Darmaraja} Kabupaten Sumedang.

Desa Cieunteung adalah salah satu desa di Kecamatan Darmaraja Kabupaten Sumedang yang mendapatkan bantuan PKH. Desa Cienteung dipimpin oleh Kepala Desa dan untuk melaksanakan tugasnya, Kepala Desa dibantu oleh Seksi Pemerintahan, Seksi Kesejahteraan, dan Seksi Pelayanan. Seksi Pemerintahan memiliki fungsi melaksanakan manajemen 
tata praja pemerintahan, menyusun rancangan regulasi desa, pembinaan masalah pertanahan, pembinaan ketentraman dan ketertiban, pelaksanaaan upaya perlindungan masyarakat, kependudukan, penataan dan pengelolaan wilayah, serta pendataan dan pengelolaan profil desa. Seksi Kesejahteraan menjalankan fungsi pelaksanaan pembangunan sarana prasarana pedesaan, pembangungan bidang pendidikan, kesehatan dan tugas sosialisasi serta motivasi masyarakat di bidang budaya, ekonomi, politik, lingkungan hidup, pemberdayaan keluarga, pemuda, olahraga, dan karang taruna. Sedangkan Seksi Pelayanan memiliki tugas melakukan penyuluhan dan motivasi terhadap pelaksanaan hak dan kewajiban masyarakat, pelestarian nilai sosial budaya masyarakat, keagamaan dan lingkungan.

Selain dibantu oleh unsur pelaksana teknis yang terdiri dari tiga seksi tersebut, Kepala Desa Cieunteung juga dibantu oleh Kepala Dusun atau Kepala Wilayah yang terdiri dari empat Kepala Dusun yang menguasai Wilayah atau Dusun Cieunteung, Dusun Nagrog, Dusun Paniis dan Dusun Kamenteng. Kepala Desa juga dibantu oleh 6 Rukun Warga (RW) dan 26 Rukun Tetangga (RT). Kepala Dusun merupakan kepala wilayah yang memiliki tugas melakukan pembinaan ketentraman dan ketertiban, upaya perlindungan masyarakat, mobilisasi kependudukan, penataan dan pengelolaan wilayah, mengawasi pelaksanaan pembangunan wilayah, melaksanakan pembinaan kemasyarakatan dalam meningkatkan kemampuan dan kesadaran masyarakat dalam menjaga lingkungan serta melakukan upaya - upaya pemberdayaan masyarakat yang menunjang kelancaran penyelenggaraan pemerintahan dan pembangunan.

Penanganan permasalahan sosial di Desa Cieunteung secara teknis berada di bawah kewenangan Seksi Kesejahteraan. Di dalam pelaksanaannya Seksi Kesejahteraan bermitra dengan banyak pihak, baik secara internal maupun eksternal. Secara internal Seksi Kesejahteraan dalam menangani permasalahan sosial yang ada di Desa Cienteung bekerjasama dengan Kepala Dusun, Rukun Warga dan Rukun Tetangga, tokoh masyarakat non formal, organisasiorganisasi sosial, maupun dunia usaha yang ada di wilayah Desa Cieuteung. Secara eksternal, Seksi Kesejahteraan bermitra dengan Dinas Sosial, Kementerian Sosial dan pihak yang memiliki kewenangan dalam penanganan masalah sosial.

Data yang diperoleh dari hasil sensus penduduk tahun 2018 menunjukkan bahwa jumlah penduduk Desa Cieunteung ada 5.098 orang dengan jumlah Kepala Keluarga sebanyak 1.607 KK. Dari jumlah penduduk tersebut terdapat penduduk miskin yang dikelompokkan menjadi: 1) Fakir Miskin sebanyak 214 Kepala Keluarga, dan 2) Perempuan Rawan Sosial Ekonomi sebanyak 48 orang.

Penanganan masalah sosial kemiskinan di Desa Cieunteung dilakukan melalui kerjasama dengan Pemerintah Daerah Kabupaten Sumedang maupun Pemerintah Pusat khususnya Kementerian Sosial. Adapun program penanganan masalah kemiskinan yang sudah dilaksanakan di Desa Cieunteung adalah Program Keluarga Harapan (PKH) dan Bantuan Pemerintah Non Tunai (BNPT). 
Jumlah penduduk miskin di Desa Cieuteung yang mendapatkan bantuan PKH ada 260 keluarga, yang terdiri dari Keluarga Fakir Miskin, Perempuan Rawan

Sosial Ekonomi, Penyandang Disabilitas dan Keluarga yang memiliki Anak Dengan Kedisabilitasan.

\section{Anak Keluarga Penerima Manfaat PKH}

Di dalam penelitian ini fokusnya pada Keluarga Miskin sebagai Keluarga Penerima Manfaat PKH yang memiliki anak usia sekolah, yaitu berjumlah 157 keluarga. Jumlah anak usia sekolah dari Keluarga Penerima Manfaat PKH ada 355 anak, yang terdiri dari 163 anak Sekolah Dasar (SD), 87 anak Sekolah Lanjutan Pertama (SLTP), dan 85 anak Sekolah Lanjutan Atas (SLTA). Adapun yang menjadi responden di dalam penelitian ini adalah anak SLTP sebanyak 60 anak, yang terdiri dari 26 anak laki-laki, 34 anak perempuan dan anak SLTA sebanyak 59 anak, yang terdiri dari 30 anak laki-laki. 29 anak perempuan

\section{Keterampilan Sosial Anak Keluarga Penerima Manfaat PKH}

Keterampilan sosial anak Keluarga Penerima Manfaat PKH digambarkan melalui keterampilan kerjasama, keterampilan asertif, keterampilan tanggung jawab, keterampilan empati dan keterampilan kendali diri. Berikut adalah hasil penelitian mengenai keterampilan sosial anak Keluarga Penerima Manfaat PKH:

\section{a. Keterampilan sosial anak Keluarga} Penerima Manfaat PKH berdasarkan tingkat pendidikan dan jenis kelamin pada aspek kerjasama.

Keterampilan sosial anak berdasarkan aspek kerjasama diukur melalui perilaku anak di sekolah, khususnya ketika anak menyampaikan ide pada saat membahas materi bersama temannya, menanyakan materi pada temannya, mendorong temannya untuk berpartisipasi di dalam kegiatan kelompok, memastikan makna dari pernyataan temannya. Hasil penelitian menunjukkan bahwa keterampilan sosial anak SLTA pada aspek kerjasama yang ada pada kategori tinggi mencapai $24,13 \%$ untuk perempuan dan $60 \%$ untuk laki-laki, sedangkan untuk kategori sedang ada $65,51 \%$ untuk perempuan dan $23.30 \%$ untuk laki-laki, selanjutnya pada kategori rendah $10,34 \%$ untuk perempuan dan $16,70 \%$ untuk laki-laki. Keterampilan sosial pada aspek kerjasama anak SLTP menunjukkan bahwa pada kategori tinggi ada $50 \%$ untuk perempuan dan $11,53 \%$ untuk laki-laki, selanjutnya untuk kategori sedang ada $32,35 \%$ untuk perempuan dan $69,23 \%$ untuk laki-laki, sedangkan untuk kategori rendah ada $17,64 \%$ untuk perempuan dan 19,23\% untuk laki-laki.

b. Keterampilan sosial anak Keluarga Penerima Manfaat PKH berdasarkan tingkat pendidikan dan jenis kelamin pada aspek asertif.

Keterampilan sosial anak berdasarkan aspek asertif diukur melalui kemampuan anak untuk menyampaikan ketidakenakan pada saat temannya mengganggu dirinya, melindungi diri dari gangguan temannya, meminta temannya untuk berhenti mengganggunya, memberikan penjelasan 
terkait dengan kritikan yang diarahkan kepadanya, membela teman yang dizalimi. Hasil penelitian menunjukkan bahwa keterampilan sosial anak SLTA pada aspek asertif yang mencapai kategori tinggi ada $34,48 \%$ untuk perempuan dan $40 \%$ untuk laki-laki, sedangkan untuk kategori sedang ada $51,72 \%$ untuk perempuan dan $43,30 \%$ untuk laki-laki, kemudian untuk kategori rendah ada $13,79 \%$ untuk perempuan dan $16,70 \%$ untuk laki-laki. Selanjutnya keterampilan sosial anak usia SLTP pada aspek asertif yang mencapai kategori tinggi ada $50 \%$ untuk perempuan dan $26,93 \%$ untuk laki-laki, yang ada pada kategori sedang berjumlah $38,23 \%$ untuk perempuan dan $50 \%$ untuk laki-laki, dan yang ada pada kategori rendah ada $11,76 \%$ untuk perempuan dan 23,07\% untuk laki-laki.

\section{c. Keterampilan sosial anak Keluarga}

Penerima Manfaat PKH berdasarkan tingkat pendidikan dan jenis kelamin pada aspek tanggungjawab.

Keterampilan sosial anak berdasarkan aspek tanggung jawab diukur melalui kemampuan anak dalam bertanya dan menjawab pertanyaan, memperhatikan penjelasan guru di kelas, mengikuti diskusi di kelas, menyelesaikan tugas yang diberikan oleh guru, mengikuti peraturan yang telah disepakati, melaksanakan perannya di dalam kelompok. Hasil penelitian menunjukkan bahwa keterampilan sosial anak SLTA berdasarkan aspek tanggung jawab yang mencapai kategori tinggi berjumlah $31,03 \%$ untuk perempuan dan 30\% untuk laki-laki, selanjutnya yang ada pada kategori sedang mencapai 68,96\% untuk perempuan dan $66,67 \%$ untuk laki-laki, yang ada pada kategori rendah 3,33\% hanya untuk anak laki-laki. Keterampilan sosial anak SLTP berdasarkan aspek tanggung jawab yang ada pada kategori tinggi berjumlah 73,53\% untuk perempuan dan $38,46 \%$ untuk lakilaki, kemudian yang ada pada kategori sedangan berjumlah $20,58 \%$ untuk perempuan dan $50 \%$ untuk laki-laki, selanjutnya untuk kategori rendah ada 5,59\% untuk perempuan dan $11,54 \%$ untuk lakilaki.

\section{d. Keterampilan sosial anak Keluarga Penerima Manfaat PKH berdasarkan tingkat pendidikan dan jenis kelamin pada aspek empati.}

Keterampilan sosial anak berdasarkan aspek empati digambarkan melalui kemampuan anak dalam mengenali perasaan orang lain yang sedang marah kepadanya, kemampuan membayangkan kejadian yang dialami temannya, merasa ikut berduka ketika melihat kegagalan temannya, kemampuan mendampingi temannya yang berduka, kesediaan membantu teman jika diminta, mampu mendengarkan dengan baik curahan hati temannya. Hasil penelitian menunjukkan bahwa keterampilan sosial anak SLTA pada aspek empati yang ada pada kategori tinggi mencapai $34,48 \%$ untuk perempuan dan $30 \%$ untuk laki-laki, yang ada pada kategori sedang berjumlah 58,62\% untuk perempuan dan $60 \%$ untuk laki-laki, sedangkan yang ada pada kategori rendah berjumlah $6,90 \%$ untuk perempuan dan $10 \%$ untuk laki-laki. Keterampilan sosial anak SLTP berdasarkan aspek empati yang ada pada kategori tinggi berjumlah 52,94\% untuk perempuan dan $34,61 \%$ untuk lakilaki, kemudian yang ada pada kategori sedang berjumlah $32,35 \%$ untuk perempuan dan 53,84\% untuk laki-laki, selanjutnya untuk kategori rendah berjumlah 14,70\% 
untuk perempuan dan $11,53 \%$ untuk lakilaki.

\section{e. Keterampilan sosial anak Keluarga Penerima Manfaat PKH berdasarkan tingkat pendidikan dan jenis kelamin pada aspek kendali diri.}

Keterampilan sosial anak Keluarga Penerima Manfaat PKH berdasarkan aspek kendali diri diukur melalui kemampuan anak untuk berbuat baik bagi keluarganya, kemampuan mengatasi kesalahpahaman dengan temannya melalui kesepakatan, menyelesaikan perdebatan, menahan emosi saat dimarahi, menerima kritikan tanpa perasaan marah, menyampaikan ketidaksetujuan tanpa emosi. Hasil penelitian menujukkan bahwa anak SLTA keterampilan sosialnya berdasarkan aspek kendali diri yang mencapai kategori tinggi ada $31,03 \%$ untuk perempuan dan $23,30 \%$ untuk laki-laki, sedangkan yang mencapai kategori sedang ada $65,52 \%$ untuk perempuan dan $66,70 \%$ untuk laki-laki, selanjutnya yang ada pada kategori rendah berjumlah 3,45\% untuk perempuan dan $10 \%$ untuk laki-laki. Keterampilan sosial anak SLTP berdasarkan aspek kendali diri yang ada pada kategori tinggi berjumlah $70,58 \%$ untuk perempuan dan 19,24\% untuk lakilaki, kemudian yang ada pada kategori sedang berjumlah $29,59 \%$ untuk perempuan dan 30,76\% untuk laki-laki, sedangkan yang ada pada kategori rendah berjumlah $8,83 \%$ untuk perempuan dan $50 \%$ untuk laki-laki.Rekapitulasi hasil penelitian mengenai keterampilan sosial anak Keluarga Penerima Manfaat PKH secara lebih jelas digrambarkan dalam grafik berikut:

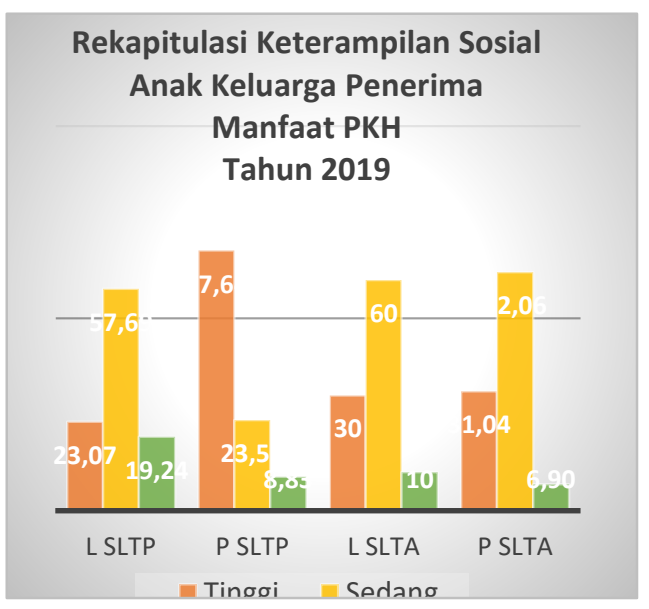

Gambar 1: Grafik rekapitulasi data keterampilan sosial anak Keluarga Penerima Manfaat PKH berdasarkan tingkat pendidikan dan jenis kelamin .

Data pada grafik tersebut menunjukkan bahwa keterampilan sosial anak Keluarga Penerima Manfaat PKH baik laki-laki maupun perempuan, yang ada di SLTP maupun SLTA sebagian besar ada pada kategori sedang, yaitu berkisar antara $57 \%$ - $62 \%$ artinya bahwa anak-anak Keluarga Penerima Manfaat PKH memiliki keterampilan sosial yang cukup baik. Grafik tersebut juga menunjukkan bahwa anak perempuan di SLTP memiliki keterampilan sosial yang sangat menonjol, yaitu ada pada kategori tinggi sebanyak 67,64\%. Namun demikian masih ada anak Keluarga Penerima Manfaat PKH yang memiliki keterampilan sosial dalam kategori rendah yaitu sekitar $20 \%$.

\section{PEMBAHASAN}

Keterampilan sosial bagi seorang siswa yang sedang menempuh pendidikan adalah sangat penting yaitu berfungsi untuk mempermudah siswa dalam menyelesaikan studinya dengan prestasi yang memuaskan. Bantuan kepada anak Keluarga Penerima Manfaat PKH hanya dapat diberikan jika 
anak dapat menjaga keberlangsungan pendidikannya. Keberhasilan anak dalam menyelesaikan pendidikannya tergantung kepada kemampuannya untuk akses terhadap sistem sumber yang tersedia di lingkungannya. dan akses terhadap sistem sumber tersebut memerlukan keterampilan sosial. Keterampilan sosial anak berkembang melalui bantuan dari lingkungan sosialnya terutama dari keluarganya. Keluarga merupakan sumber pembelajaran dan memberikan model untuk pengembangan keterampilan sosial anak.

Hasil penelitian menunjukkan bahwa keterampilan sosial anak Keluarga Penerima Manfaat PKH sebagian besar ada pada kategori sedang yaitu berkisar antara 57\% $62 \%$, artinya bahwa keterampilan sosial anak Keluarga Penerima Manfaat PKH sudah baik. Kondisi tersebut tidak lepas dari peran berbagai pihak diantaranya adalah: 1) Orang tua, mempunyai peran yang sangat penting di dalam mendorong anaknya untuk bertahan dalam menyelesaikan pendidikannya. Hal tersebut juga disadari oleh anak bahwa bantuan PKH hanya dapat diterima jika anak tetap melanjutkan pendidikannya; 2) Peran pendamping $\mathrm{PKH}$ yang memberikan pelatihan parenting kepada Keluarga Penerima Manfaat PKH agar dapat memberikan pengasuhan yang tepat kepada anak-anaknya dan membantu menyelesaikan permasalahan yang dihadapi anak. Sebagaimana penjelasan tentang PKH dalam Pedoman Pelaksanaan Program Keluarga Harapan oleh Kementerian Sosial (2018) bahwa salah satu tujuan dari Pertemuan Peningkatan Kemampuan Keluarga adalah: meningkatkan pengetahuan Keluarga Penerima Manfaat PKH mengenai pengasuhan anak dan mendukung pendidikan anak di sekolah; 3) Peran tenaga pendidik di sekolah anak yang ikut memonitor perkembangan pendidikan anak dan membantu mengatasi masalah belajar anak.

Hasil penelitian tentang keterampilan sosial anak juga menggambarkan bahwa keterampilan sosial anak perempuan khususnya yang ada di SLTP sebagian besar ada pada kategori tinggi yaitu 67,64\%, Fakta tersebut dapat dijelaskan melalui pendapat dari Leaper (2002) bahwa strategi pengasuhan menjadi mediasi hubungan antara gender dan kompetensi sosial.. Orang tua lebih banyak melakukan interaksi verbal dengan anak perempuannya dibandingkan dengan anak laki-lakinya karena anak perempuan lebih responsif. Komunikasi verbal tersebut mempermudah individu dalam mengembangkan keterampilan sosialnya.

\section{Keterampilan sosial anak Keluarga Penerima Manfaat PKH berdasarkan aspek kerjasama.}

Hasil penelitian menunjukkan bahwa keterampilan sosial berdasarkan aspek kerjasama menunjukkan bahwa anak lakilaki di tingkat SLTA yang ada pada kategori tinggi mencapai $60 \%$ sedangkan untuk tingkat SLTP anak perempuan keterampilan kerjasamanya sebagian besar yaitu 50\% ada pada kategori tinggi. Belum ada bukti yang dapat menjelaskan perbedaan jenis kelamin dalam perilaku kerjasama. Maccoby \& Jacklin (1974) melakukan kajian perbedaan laki-laki dan perempuan di dalam perilaku sosial, mereka menemukan bahwa di dalam sebagian besar domain perilaku termasuk kerjasama hasil penelitiannya tidak meyakinkan (Balliet et. al., 2011). Penelitian tentang perilaku ekonomi (Eckel \& 
Grossman; 2001; Solnick, 2001) dan permainan diktator (Andreoni \& Vesterlund, 2001; Bolton \& Katok, 1995; Dufwenberg \& Muren, 2006) yang digambarkan dalam karya Balliet et. al. (2011) juga tidak menemukan perbedaan jenis kelamin yang sistematik pada perilaku kerjasama. Peneliltian ini dilakukan dalam beberapa dekade dan hasilnya menjelaskan bahwa laki-laki dan perempuan memiliki keterampilan kerjasama yang sama. Keterampilan kerjasama sangat bermanfaat untuk membantu anak dalam memenuhi kebutuhan pendidikan mereka, seperti memperoleh dukungan guru, teman sekolah, dan orang-orang yang ada di lingkungan sosialnya. Hal tersebut sesuai dengan hasil studi yang dilakukan oleh Erden (2009) yang menggambarkan bahwa kerjasama di dalam proses belajar dapat mempermudah siswa untuk: 1) berbagi tugas diantara para siswa, 2) membantu para siswa untuk memecahkan masalah melalui interaksi diantara siswa, 3) mengembangkan hubungan diantara siswa, 4) membantu siswa untuk menggunakan waktunya secara optimal (Lavasani, Afzali \& Afzali, 2011). Sebaliknya siswa yang kurang dapat melakukan kerjasama dengan siswa lain akan mendapatkan penolakan dan menimbulkan kesulitan di dalam proses belajar. Program Family Development Season dari PKH, bermanfaat didalam membantu keluarga untuk mengembangkan keterampilan kerjasama anak. Walaupun demikian masih ada sebagian kecil anak Keluarga Penerima Manfaat PKH di tingkat pendidikan SLTP maupun SLTA baik yang laki-laki maupun perempuan ada pada kategori rendah yaitu berkisar antara 10\% 20\%. Keluarga Penerima Manfaat PKH merupakan keluarga miskin. Pengasuhan anak di dalam keluarga miskin umumnya kurang mendukung perkembangan keterampilan sosial anak karena kondisi kehidupan keluarga yang tidak kondusif. Hal tersebut sesuai dengan penjelasan dari Conger (1994) tentang "Family Stress Model" yang menggambarkan bahwa pengalaman hidup dalam kemiskinan menjadi suatu faktor yang mengganggu hubungan pasangan suami istri, menimbulkan perasaan depresi dan disfungsi keluarga yang selanjutnya berpengaruh pada pengasuhan terhadap anak. Umumnya orang tua berpenghasilan rendah kurang mampu dalam memonitor anak-anaknya, memberikan dukungan dan kehangatan, di dalam mendisiplinkan anak, menunjukkan ketidaksukaan dan agresif terhadap anak (Ahmed, 2005). Pendapat Conger dalam Ahmed tersebut menggambarkan bahwa ada kemungkinan sebagian Keluarga Penerima Manfaat PKH yang merupakan keluarga miskin kondisinya tidak kondusif bagi pengembangan keterampilan sosial anak, khususnya pada aspek kerjasama

\section{Keterampilan sosial anak Keluarga Penerima Manfaat PKH berdasarkan aspek asertif.}

Hasil penelitian menunjukkan bahwa keterampilan sosial anak Keluarga Penerima Manfaat PKH berdasarkan aspek asertif, anak perempuan yang ada pada tingkat SLTP sebagian besar yaitu $50 \%$ memiliki keterampilan asertif tinggi, sedangkan anak laki-laki di tingkat SLTA sebagian besar yaitu $40 \%$ juga memiliki keterampilan asertif yang tinggi. Hasil penelitian ini menunjukkan tidak ada perbedaan pada keterampilan asertif pada anak perempuan dan anak laki-laki. Hasil penelitian ini sesuai 
dengan hasil penelitian yang dilakukan oleh Eskin (2003), Qadir \& Sugumar (2013), Uzaina \& Parveen (2015) bahwa tidak ada perbedaan gender dalam perilaku asertif walaupun awalnya penelitian mereka didasari oleh asumsi bahwa perempuan kurang asertif daripada laki-laki karena faktor hambatan dan adanya taboo dalam budaya. Laki-laki dipandang lebih asertif karena mereka memiliki kepribadian yang kuat dan bijaksana (Parray \& Kumar, 2016).

Faktor usia juga mempunyai kaitan dengan perilaku asertif anak. Burhmester (1990) menjelaskan bahwa pada anak kecil perilaku asertifnya belum terbentuk karena struktur kognitifnya belum memungkinkan mereka untuk menyatakan apa yang diinginkan dengan bahasa verbal yang baik dan jelas. Pada masa remaja dan dewasa kemampuan asertif menjadi berkembang. Anak dalam penelitian ini adalah anak yang masuk pada periode remaja yaitu pada tingkat pendidikan SLTP dan SLTA, sehingga nampak bahwa keterampilan asertifnya sebagian besar ada pada kategori tinggi.

Selanjutnya anak-anak di SLTP dan SLTA merupakan anak-anak yang memasuki masa remaja, dimana pengaruh teman sebaya sangat besar dalam kehidupan remaja. Keterampilan asertif sangat bermanfaat bagi remaja untuk melindungi diri dari pengaruh buruk lingkungan sosialnya, hal tersebut sesuai dengan pendapat Ghodrati, Travokali, Heyadry, \& Akbarzadeh (2016) bahwa pada masa remaja, anak sering menghadapi tekanan dari teman sebayanya, dan keterampilan asertif dapat melindungi diri anak dari faktor-faktor yang mengancam kesehatannya (Sitota : 2018).
Selanjutnya Seguided menjelaskan bahwa keterampilan asertif adalah suatu cara yang digunakan oleh individu untuk berkomunikasi secara sehat dan merupakan kemampuan yang dimiliki oleh individu untuk mengungkapkan dirinya secara jujur dan terhormat. Orang yang asertif dapat menyampaikan permintaan dan penolakan secara tegas namun sopan, selain itu ia juga memiliki kepedulian terhadap perasaan orang lain (Sitota : 2018). Seguided juga menjelaskan bahwa keterampilan asertif dapat membantu siswa untuk meningkatkan keterampilan komunikasi, memberikan penghargaan pada diri sendiri, kemampuan dalam membuat keputusan, mengatasi rasa malu dan marah, membantu siswa untuk memiliki waktu lebih banyak bagi aktivitas belajar yang kesemuanya akan membantu siswa untuk memperbaiki konsepsi tentang sekolah secara positif. Sebaliknya jika siswa berperilaku atau berinteraksi secara tidak asertif maka ia akan mengalami hambatan di dalam pemenuhan kebutuhannya.

Hasil penelitian menunjukkan bahwa masih terdapat anak dari Keluarga Penerima Manfaat PKH baik yang laki-laki maupun perempuan, yang ada di tingkat SLTP maupun SLTA keterampilan asertifnya ada pada kategori rendah yaitu sekitar $24 \%$.

Anak dengan keterampilan asertif yang rendah menghadapi resiko menjadi target manipulasi teman sebayanya dan lingkungan sosial lainnya, dan sebagai siswa akan menghadapi kesulitan untuk akses sumber belajar yang dibutuhkannya sehingga berakibat pada penurunan prestasi akademiknya. Kondisi kemiskinan Keluarga Penerima Manfaat PKH dapat menimbulkan kesadaran anak tentang 
kekurangan dirinya dibandingkan dengan anak-anak lain dari keluarga mampu. Kondisi kekurangan yang disadari oleh anak dapat berkaitan dengan kemampuan asertifnya, mereka tidak memiliki kekuatan untuk menolak tekanan teman sebayanya. Kondisi tersebut perlu menjadi perhatian khusus bagi keluarga dan pendamping PKH.

\section{Keterampilan sosial anak Keluarga} Penerima Manfaat PKH berdasarkan aspek tanggungjawab.

Hasil penelitian menunujukkan

bahwa sebagian besar keterampilan ntanggung jawab anak Keluarga Penerima Manfaat PKH berada pada kategori sedang yaitu antara 50\% - 70\% baik untuk anak lakilaki dan perempuan yang di SLTP maupun SLTA. Hasil penelitian juga menunjukkan bahwa anak perempuan yang ada di tingkat pendidikan SLTP sebagian besar yaitu 73,53\% ada pada kategori tinggi. Kondisi tersebut menggambarkan bahwa Keluarga Penerima Manfaat PKH menyadari perannya dalam mendorong pendidikan anak, karena pendidikan adalah salah satu syarat untuk mendapatkan bantuan PKH. Perhatian orang tua terhadap aktivitas pendidikan yang dijalani anak mendorong anak untuk dapat mengikuti proses pendidikannya dengan baik. Anak berusaha mengembangkan tanggung jawabnya di lingkungan sekolahnya dengan menunjukkan kehadiran di kelas. Kehadiran di kelas merupakan satu cara untuk mengontrol aktivitas pendidikan anak yang diverifikasi oleh pendamping PKH. Tanggungjawab yang lain berkaitan dengan penyelesaian tugas-tugas yang diberikan oleh guru, dan mengikuti aktivitas lain di sekolah.
Walaupun sebagian besar keterampilan tanggung jawab anak ada pada kategori sedang, namun demikian masih ada anak yang keterampilan tanggungjawabnya ada pada kategori rendah yaitu sebanyak $12 \%$. Kondisi tersebut nampaknya sesuai dengan pendapat yang dikemukakan oleh Jensen (2009) yang menggambarkan bahwa anak yang diasuh dalam keluarga miskin seringkali mengalami hambatan di dalam mempelajari respon yang tepat dalam situasi kehidupan sehari-hari yang selanjutnya dapat merugikan anak pada saat berada di sekolahnya. Disfungsi sosial anak di sekolah akan mengurangi kemampuan anak untuk melakukan kerjasama di dalam kelompok, yang selanjutnya akan menyebabkan anak mendapatkan penolakan dari kelompoknya karena anggota kelompok yang lain meyakini bahwa anak dari keluarga miskin tidak dapat mengerjakan bagiannya dengan baik sebagai anggota kelompok. Penolakan anak dari kelompok, akan disertai dengan menurunnya pertukaran informasi. Kondisi tersebut akan mengganggu pengembangan keterampilan tanggungjawab anak di dalam menyelesaikan tugas-tugas akademiknya, yang selanjutnya akan membahayakan keberhasilan anak dalam menyelesaikan pendidikannya.

4. Keterampilan sosial anak Keluarga Penerima Manfaat PKH berdasarkan aspek empati.

Hasil penelitian menunjukkan bahwa keterampilan empati anak Keluarga Penerima Manfaat PKH di SLTP dan SLTA untuk laki-laki dan perempuan sebagian besar ada pada kategori sedang yang berkisar antara 30\% - 60\%, artinya keterampilan empati anak dari Keluarga Penerima 
Manfaat PKH ini sudah baik dan sangat membantu anak-anak tersebut dalam mengikuti proses belajar di sekolah karena keterampilan empati dapat menjadi alat untuk mengembangkan relasi dengan guru, teman sekolah dan pihak yang lain yang dapat menjadi sumber pembelajaran. Hal tersebut sesuai dengan pendapat Brigs (2014) bahwa empati merupakan keterampilan yang dapat membantu anak muda lebih produktif di lingkungan yang membutuhkan kerjasama. Empati dapat mengurangi keegoisan, mendorong terjadinya perilaku prososial, sedangkan kurangnya empati dapat menyebabkan terjadinya perilaku antisosial. Selanjutnya Brigs (2014) menjelaskan bahwa empati memiliki manfaat untuk mempermudah: 1) pemahaman terhadap adanya perbedaan pendapat dan meningkatkan keterbukaan pemikiran; 2) mencegah melihat masalah secara dangkal dan terburu-buru; 3) pengembangan model pemecahan masalah yang baru; 4) mencegah keyakinan yang kaku; 5) fleksibilitas kognitif dan kepribadian; 6) mendorong orang untuk menggali, membahas isu-isu perubahan dengan fleksibel. Pendapat lain yaitu dari Gordon \& Green (2009) tentang manfaat empati bagi pengembangan kompetensi sosial adalah bahwa pengembangan kompetensi sosial emosional dan empati dapat meningkatkan tanggung jawab moral pada anak terhadap kesejahteraan teman sebayanya. Kepedulian anak terhadap orang lain akan menimbulkan respon positif dari lingkungan sosialnya. Empati sangat bermanfaat bagi siswa, karena empati dapat membantu siswa dalam membangun hubungan yang lebih kuat dan nyaman dengan siswa lain maupun dengan guru, serta menimbulkan perasaan nyaman pada diri anak dalam mengikuti proses belajar di sekolah, mendorong orang lain untuk memberikan toleransi dan penerimaan pada siswa, meningkatkan keharmonisan sosial dan mengurangi terjadinya bullying, kondisi yang dialami siswa tersebut selanjutnya akan dapat meningkatkan kesehatan mentalnya (Yother:2013). Anak menjadi merasa nyaman di sekolah. Kemampuan empati anak Keluarga Penerima Manfaat PKH yang cukup baik sangat bermanfaat untuk mencapai keberhasilan pendidikan.

\section{Keterampilan sosial anak Keluarga Penerima Manfaat PKH berdasarkan aspek kendali diri.}

Hasil penelitian selanjutnya menggambarkan keterampilan sosial anak Keluarga Penerima Manfaat PKH berdasarkan apek kendali diri. Hasil penelitian menunjukkan bahwa anak Keluarga Penerima Manfaat PKH di SLTP khususnya untuk anak perempuan sangat menonjol yaitu sebagian besar atau 70,58\% ada pada kategori tinggi. Sedangkan untuk anak Keluarga Penerima Manfaat PKH di SLTA baik yang laki laki maupun yang perempuan sebagian besar memiliki keterampilan kendali diri pada kategori sedang yaitu sekitar 57\% - 62\%, artinya bahwa keterampilan sosial anak Keluarga Penerima Manfaat PKH dari aspek kendali diri ini sudah baik. Seseorang yang memiliki keterampilan kendali diri tinggi akan memudahkannya dalam mengembangkan hubungan yang harmonis dengan orang lain, membantu di dalam menahan diri untuk tidak berkata kasar atau melakukan sesuatu yang tidak tepat kepada orang lain. Bagi siswa menurut Tangney, 
Baumeister, \& Boone (2004) memiliki keterampilan kendali diri yang tinggi sangat bermanfaat di dalam mengarahkan tindakannya untuk mencapai prestasi akademik yang tinggi karena mereka dapat menyelesaikan tugasnya tepat waktu dan menggunakan lebih banyak waktunya untuk belajar, menghindari penggunaan waktu luang yang dapat mengganggu proses belajarnya (Ryckman, 2013).

Hasil penelitian juga menunjukkan bahwa anak laki-laki Keluarga Penerima Manfaat PKH yang ada di SLTP setengahnya yaitu $50 \%$ ada pada kategori rendah. Hal tersebut sesuai dengan pendapat Stuke \& Baumeister (2006) bahwa seseorang bukan hanya di kalangan pelajar tetapi juga terjadi di kalangan umum yang memiliki keterampilan kendali diri kurang seringkali mengalami permasalahan yang cukup besar seperti menjadi pecandu alkohol, pengguna obat-obat terlarang, menyerang orang lain secara pisik, dan melakukan kekerasan kepada orang lain. Remaja dan orang dewasa yang keterampilan kendali dirinya kurang seringkali bertindak impulsif, mencaci orang lain ketika kecewa, dan ketika mereka mengalami stres kehidupan maka mereka mempunyai kecenderungan menjadi perokok, pengguna alkohol, dan obat-obat terlarang (Ryckman, 2013). Memperhatikan pendapat Stuke \& Baumeister tersebut, maka baik keluarga maupun pendamping $\mathrm{PKH}$ perlu memperhatikan secara khusus kepada anak-anak yang keterampilan kendali dirinya rendah karena melihat dampaknya yang akan menimbulkan permasalahan pada anak khususnya di lingkungan sekolah.

\section{KESIMPULAN}

Kesimpulan dari penelitian ini adalah bahwa sebagian besar yaitu antara $57 \%$ - 62\% keterampilan sosial anak Keluarga Penerima Manfaat PKH di SLTP dan SLTA baik laki-laki aupun perempuan ada pada kategori sedang, bahkan keterampilan sosial anak perempuan di SLTP sebagian besar yaitu $67,74 \%$ ada pada kategori tinggi, artinya bahwa keterampilan sosial mereka sudah baik. Kondisi tersebut tentunya tidak terlepas dari peran $\mathrm{PKH}$ khususnya dalam Program Pertemuan Peningkatan Kemampuan Keluarga, yang di dalam program tersebut pendamping PKH memberikan pengetahuan dan keterampilan pengasuhan anak serta meningkatkan kesadaran kepada keluarga untuk mendampingi aktivitas pendidikan anak-anaknya sehingga anak mampu menyelesaikan target pendidikannya sebagaimana haraparan dari PKH untuk memutus rantai kemiskinan melalui peningkatan kualitas generasi muda dari keluarga miskin. Namun demikian jika keterampilan sosial dilihat dari aspekaspeknya, masih ada yang perlu mendapat perhatian khusus, yaitu pada aspek kendali diri anak laki-laki di SLTP setengahnya atau $50 \%$ ada pada kategori rendah, demikian pula pada aspek keterampilan asertif untuk anak perempuan $50 \%$ nya ada pada kategori rendah. Berdasarkan hal tersebut maka direkomendasikan sebagai berikut: 1) Bagi Kementerian Sosial, perlu pengembangan modul pelatihan keterampilan sosial untuk Pertemuan Peningkatan Kemampuan Keluarga, perlu memberikan pelatihan bagi intervensi terhadap masalah keterampilan sosial bagi pendamping $\mathrm{PKH}$; 2) Bagi Pendamping $\mathrm{PKH}$, perlu secara proaktif 
belajar meningkatkan kemampuan intervensi untuk membantu mengatasi masalah keterampilan sosial anak Keluarga Penerima Manfaat PKH; 3) Penelitian lanjutan diarahkan pada variabel yang terkait dengan perkembangan keterampilan sosial anak, seperti pola pengasuhan keluarga yang mendukung keterampilan sosial anak, peran pendamping PKH dalam mengatasi masalah keterampilan sosial anak Keluarga Penerima Manfaat PKH.

\section{DAFTAR PUSTAKA}

Ahmed, Z. S. (2005). Poverty, family stress \& parenting. Australia: Deakin University

Balliet, D.; Norman, P. Li, Macfarlan, S. J.; \& Vugt, M. V. (2011). Sex difference in cooperation: A meta-analytic review of social dilemmas. Psychological Bulletin. Vol. 137(6) 881-909

Barnes, S. (2007). Peer Relationship, Protective Factory, and Social Skill Development in Low-income Children. Applied Psychology Opus

Beheshtifar, M., \& Norozy, T. (2013). Social skills: A factor to employees' success. International Journal of Academic Research in Business and Social Sciences.3(3).

Brigs, S. (2014). How empathy affects learning, and how to cultivative it in your studens. https://www. opencolleges.edu.au.e

Buhrmester, D. (1990). Intimacy of friendship, interpersonal competence. Journal of Personality and Social Psychology. Vol. 24(1) 1-4

Conger, R. D., Conger, G. H., Elder Jr., F. O. Lorenz \& R. L. Simons. (1994). Economic stress, coercive family process and developmental problems of adolescents. Child Development. 65:541 - 61

Gresham, F.M. (2016). Social skills assessment and intervention for children and youth. Cambridge Journal of Education, 46(3), 319-332

Jensen, E. (2009). Teaching With Powerty In Mind. What Being Poor Does to Kids Brains and Hwa School Can Do About It. ACSD

Kementerian Sosial. (2018). Pedoman pelaksanaan Program Keluarga Harapan. Jakarta

Lavasani, M. G., Afzali, L., \& Afzali, F. (2011). Cooperative learning and social skills. Cypriot Journal of Educational Sciences.4(2011) 186 - 193

Leaper, C. (2002). Parenting girls and boys in M. H. Bornstein $(E d)$. Handbook of parenting: Children and parenting. Lawrence Erlbaum Associates Publishers.

Parray, W. M.; \& Kumar, S. (2016). Assertiveness among undergraduate students of the university. The International Journal of Indian Psychology. 4(1)-76

Ryckman, R. M. (2013). Theories of Personality. Belmont, CA: Wadsworth, Cengage Learning.

Sitota, G. (2018). Assertiveness and academic achievement motivation of adolescent in selected Secondary Scholls of Harari Peoples Regional State, Ethiopia. Journal of Education and Literacy Studies.6(4).

Sugiyono. (2017). Metode Penelitian Kuantitatif, Kualitatif, dan $R \& D$. Bandung: Alfabeta, CV.

Yother, R. J. (2013). The impact of specialized treatment on the empathy levels of urban, low-income, third and fourth grade 
